\title{
PENYULUHAN TENTANG BAHAYA PENYALAHGUNAAN NARKOTIK, PSIKOTROPIKA DAN ZAT ADITIF BAGI SISWA SISWI SMA DAN SMK MUTIARA 17 AGUSTUS
}

\author{
Dwitiyanti* | Kriana Efendi | Supandi \\ Fakultas Farmasi dan Sains Universitas Muhammadiyah Prof. DR. HAMKA
}

\begin{abstract}
Abstrak
Pengabdian masyarakat yang dilaksanakan berjudul "Penyuluhan Tentang Bahaya Penyalahgunaan Narkotik, Psikotropika Dan Zat Aditif Bagi Siswa Siswi SMA dan SMK Mutiara 17 Agustus", bertujuan untuk meningkatkan pengetahuan dan kesadaran siswa akan dampak negatif dari penyalahgunaan NAPZA serta mengarahkan remaja untuk menyalurkan energi dalam berbagai kegiatan positif, serta meningkatkan meningkatkan kewaspadaan dan membentuk pertahanan diri terhadap bahaya yang ditimbulkan dari penyalahgunaan NAPZA. Target yang dicapai adalah meningkatkan pemahaman dan memberikan informasi terkait penggunaan, bahaya dan dampak dari penyalahgunaan NAPZA. Metode pelaksanaan kegiatan Pemberdayaan dan Pengabdian Masyarakat pada mitra berupa Pemetaan terhadap siswa dengan cara Mendata jumlah siswa, jenis kelamin, umur, hobi, merokok/tidak. Melakukan penyuluhan dengan cara menjelaskan tentang pengertian obat narkotik psikotropik dan zat aditif lain, dampak negatif yang ditimbulkan dari penyalahgunaan NAPZA, diskusi dan tanya jawab, pembagian leaflet sadar akan penyalahgunaan NAPZA serta evaluasi. Hasil dari pengabdian ini menunjukan bahwa siswa siswi memiliki pemahaman yang meningkat dibandingkan sebelum diberikan penyuluhan tentang Napza dan dampak buruknya, sehingga meningkatkan kesadaran siswa akan dampak yang bisa ditimbulkan.
\end{abstract}

Kata Kunci: narkotik, psikotropika, zat adiktif

\section{Pendahuluan}

Obat adalah suatu zat yang digunakan untuk diagnosa pengobatan, menyembuhkan atau mencegah penyakit pada manusia atau hewan. Meskipun obat dapat menyembuhkan tapi banyak kejadian yang menyebabkan seseorang menderita akibat keracunan. Oleh karena itu dapat dikatakan obat dapat bersifat sebagai obat apabila tepat digunakan dalam pengobatan suatu penyakit dengan dosis dan waktu yang tepat (Anief 2007). Penyalahgunaan zat atau obat dari hari ke hari semakin meningkat, walaupun banyak usaha untuk menanggulangi telah diusahakan. Penyalahgunaan tidak terbatas pada orang dewasa saja tetapi telah terjadi pada anak-anak. Untuk itu sebagai pendidik dan tenaga medis kita harus mengetahui apa itu penyalahgunaan zat/obat dan apa dampaknya bagi kesehatan dan kehidupan sosial.

NAPZA (narkotik, psikotropika dan zat aditif) pada mulanya ditemukan dan dikembangkan untuk pengobatan dan penelitian. Tujuannya adalah untuk kebaikan manusia. Namun berbagai jenis obat tersebut kemudian juga dipakai untuk tujuan bukan penelitian dan pengobatan, melainkan disalahgunakan untuk mencari kenikmatan sementara atau mengatasi persoalan sementara. Pemakaian obat tanpa petunjuk medis merupakan penyalahgunaan. Penyalahgunaan NAPZA cenderung mengakibatkan ketergantungan/dependensi, atau kecanduan. Biasanya penyalahgunaan menghasilkan akibat yang serius dan dalam beberapa kasus bisa fatal dan mengakibatkan kematian serta kerugian sosial dan ekonomi.

\footnotetext{
*Penulis Korespondensi. Email: dwity.farmasi@ gmail.com
} 
Jurnal SEMAR Vol. 8 No. 1, 2019 hal. $40-43$

Berdasarkan hasil penelitian Rerata umur pertama kali pakai narkoba 16 tahun, dengan kisaran umur terendah 10 tahun dan tertinggi 27 tahun hasil survei ditahun 2016. Dua alasan terbanyak yang dikemukan adalah ingin tahu atau coba-coba dan bersenang-senang, baik pada laki-laki maupun perempuan.

Pengetahuan narkoba yang mumpuni dan adekuat dipercaya dapat mencegah dan menghindari orang pakai narkoba. Untuk itu, berbagai upaya telah dilaksanakan dalam rangka meningkatkan pengetahuan masyarakat tentang narkoba. Dari hasil studi diketahui, hampir semua (91\%) pelajar dan mahasiswa pernah mendengar jenis narkoba di tahun 2016, dengan proporsi terendah pada kelompok SMP (88\%). Jumlah median yang dapat menyebutkan nama jenis narkoba ada sebanyak 6 jenis. Ada 7 jenis narkoba yang banyak disebut adalah ganja, shabu, heroin, zat yang dihisap, kokain, analgesik yang dipakai tidak sesuai dosis dengan sengaja (berlebih), dan ekstasi. Semakin tinggi tingkat pendidikan, maka semakin banyak yang mengenali jenis-jenis narkoba.

Penelitian yang dilakukan oleh Lynam menyatakan bahwa status ekonomi mempengaruhi perilaku kenakalan remaja, individu yang berada dalam lingkungan kecil dengan status ekonomi yang serba terbatas akan lebih mungkin mengekspresikan dorongan mencari sensasi (Sensation Seeking) dalam tindakan anti sosial dibandingkan prososial seperti perilaku delinkuen (Delly,2009). Hal tersebut dapat terlihat bahwa kenakalan yang dilakukan oleh remaja adalah cara tersendiri bagi remaja tertentu untuk mengekspresikan dorongan mencari sensasi, seperti keinginan untuk melakukan tindakan yang penuh resiko demi untuk mendapatkan pengalaman baru (Sensation Seeking),

Pada kegiatan PPPM ini, yang akan menjadi objek adalah anggota siswa-siswi SMA dan SMK Mutiara 17 Agustus kelurahan Teluk Pucung, Kecamatan Bekasi Utara, Kota Bekasi, Jawa Barat. Sekolah Mutiara 17 Agustus merupakan salah satu sekolah swasta dengan tingkat Akreditasi A khususnya SMK Farmasi. Keadaan profil sekolah tersebut sangat heterogen baik ditinjau dari segi ekonomi, suku, agama dan ras. Fokus dalam kegiatan ini adalah berusaha meningkatkan kesadaran bagi siswa/siswi akan bahayanya penyalahgunaan NAPZA tambah data angka penyalahgunaan

\section{Metode Pelaksanaan}

Upaya untuk menyelesaikan permasalahan yang dihadapi oleh siswa-siswi SMA dan SMK Mutiara 17 yaitu dengan penyuluhan tentang dampak penyalahgunaan NAPZA dengan metode pendekatan sebagai berikut :

a. Pemetaan terhadap siswa

Mendata jumlah siswa, jenis kelamin, umur, hobi, merokok/tidak,

b. Metode penyuluhan

Dilakukan dengan cara menjelaskan tentang pengertian obat narkotik psikotropik dan zat aditif lain, menjelaskan dampak negatif yang ditimbulkan dari penyalahgunaan NAPZA, diskusi dan tanya jawab, serta pembagian leaflet sadar akan penyalahgunaan NAPZA.

c. Partisipasi mitra

Siswa siswi berperan aktif dalam diskusi materi dan melakukan kampanye antinarkoba di lingkungan sekolah dan sekitarnya serta terbentuk tim granat (gerakan antinarkoba) di sekolah.

d. Evaluasi

Sebelum pelaksanaan kegiatan dilakukan pretest tentang pengetahuan umum terkait obat NAPZA dan setelah kegiatan dilakukan posttest terhadap pemahaman materi yang sudah disampaikan.

\section{Hasil dan Pembahasan}

Sebelum dilakukan penyuluhan pada siswa, terlebih dahulu dilakukan evaluasi tentang pengetahuan awal siswa terkait NAPZA menggunakan kuisioner sebagai instrument. Kuisioner berisi 10 pertanyaan (terlampir), hasil evaluasi dapat dilihat pada tabel 1. Pemberian materi dilakukan setelah pelaksanaan pretest. Materi disampaikan dengan metode ceramah dan diskusi selama 3 jam. sebelum berakhir pelaksanaan sosialisasi masing-masing siswa diberikan post test kembali, brosur dan pin. 
Tabel 1. Tingkat pengetahuan siswa sebelum penyuluhan NAPZA

\begin{tabular}{|c|c|c|}
\hline Pengetahuan Siswa & Jumlah siswa & Persentase \\
\hline Baik & 31 & $47.7 \%$ \\
\hline Cukup & 26 & $40.0 \%$ \\
\hline Kurang & 8 & $12.3 \%$ \\
\hline Jumlah & 65 & $100 \%$ \\
\hline
\end{tabular}

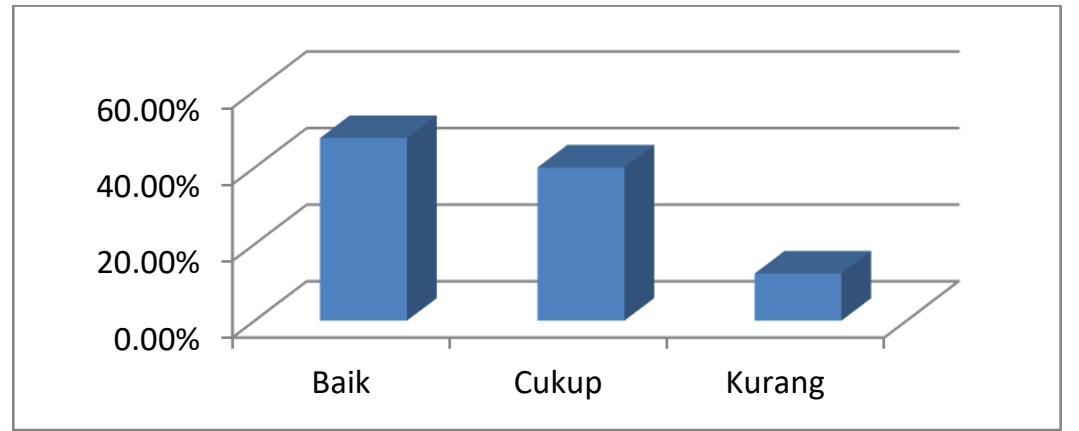

Gambar 1. Persentase tingkat pengetahuan siswa sebelum penyuluhan NAPZA

\section{Evaluasi}

Pada akhir pelaksanaan kegiatan, evaluasi dilakukan dengan mengukur tingkat pengetahuan siswa dengan mengerjakan post test dapat dilihat pada tabel 2. Hasil dari penyuluhan terkait Napza pada kegiatan ini sudah mencapai target, karena terjadi peningkatan pengetahuan, wawasan dan pemahaman siswa terkait napza dan dampak penyalahgunaan diatas $75 \%$.

Tabel 2. Tingkat pengetahuan siswa sesudah penyuluhan NAPZA

\begin{tabular}{|c|c|c|}
\hline Pengetahuan Siswa & Jumlah siswa & Persentase \\
\hline Baik & 52 & $80.0 \%$ \\
\hline Cukup & 8 & $12.3 \%$ \\
\hline Kurang & 5 & $7.7 \%$ \\
\hline Jumlah & 65 & $100 \%$ \\
\hline
\end{tabular}

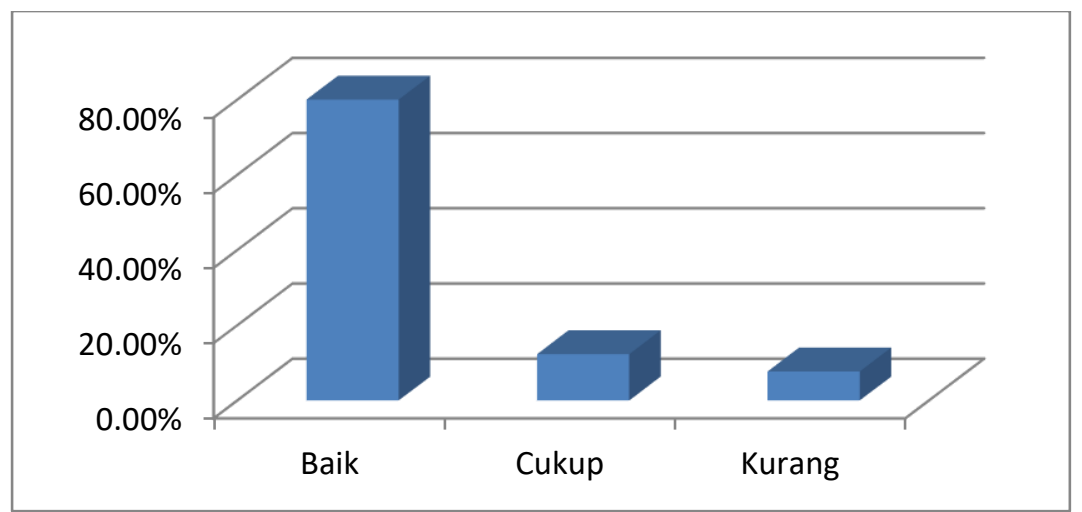

Gambar 2. Persentase tingkat pengetahuan siswa sesudah penyuluhan NAPZA

Faktor penyebab penyalahgunaan narkoba dapat dibagi menjadi dua faktor, pertama Faktor internal yaitu faktor yang berasal dari dalam diri individu seperti kepribadian, kecemasan, dan depresi serta kurangya religiusitas. Kebanyakan penyalahgunaan narkotika dimulai atau terdapat pada masa remaja, sebab remaja yang sedang mengalami perubahan biologik, psikologik maupun sosial yang pesat merupakan individu yang rentan untuk menyalahgunakan obat-obat terlarang ini. Anak atau remaja dengan ciri-ciri tertentu mempunyai risiko lebih besar untuk menjadi penyalahguna narkoba. Kedua Faktor eksternal yaitu faktor yang berasal dari luar individu atau lingkungan seperti keberadaan zat, kondisi keluarga, lemahnya hukum serta pengaruh lingkungan. 
Jurnal SEMAR Vol. 8 No. 1, 2019 hal. $40-43$

Faktor-faktor tersebut diatas memang tidak selalu membuat seseorang kelak menjadi penyalahgunaan obat terlarang. Akan tetapi makin banyak faktor-faktor diatas, semakin besar kemungkinan seseorang menjadi penyalahgunaan narkoba. Hal ini harus dipelajari Kasus demi kasus. Faktor individu, faktor lingkungan keluarga dan teman sebaya/pergaulan tidak selalu sama besar perannya dalam menyebabkan seseorang menyalahgunakan narkoba. Karena faktor pergaulan, bisa saja seorang anak yang berasal dari keluarga yang harmonis dan cukup kominikatif menjadi penyalahgunaan narkoba.

Akibat Penyalahgunaan Narkoba Penggunaan narkoba dapat menyebabkan efek negatif yang akan menyebabkan gangguan mental dan perilaku, sehingga mengakibatkan terganggunya sistem neurotransmitter pada susunan saraf pusat di otak. Gangguan pada sistem neuro-transmitter akan mengakibatkan tergangunya fungsi kognitif (alam pikiran), afektif (alam perasaan, mood, atau emosi), psikomotor (perilaku), dan aspek sosial.

Penyalahgunaan obat-obatan semakin hari oleh anak-anak menjadi masalah yang semakin memprihatinkan semua orangtua. Dari beberapa penelitian yang sudah dilakukan, disepakati bahwa membangun jalinan komunikasi intens antara orangtua dan anak merupakan alat yang ampuh untuk dapat mencegah hal-hal yang tidak diinginkan. Meskipun demikian, banyak orang tua merasa ragu mendiskusikan tentang penyalah-gunaan obat dan alkohol dengan anak-anak mereka. Sebagian dari kita percaya bahwa anak-anak kita tidak akan terlinbat pada hal-hal terlarang tersebut. Sebagian lainnya menundanya karena tidak mengetahui bagaimana mereka mengatakannya, atau justru takut mereka menjadi memikir tentang hal itu dan mendorong ke arah yang tidak diinginkan.

\section{Kesimpulan}

Narkoba adalah obat obatan terlarang yang jika dikonsumsi mengakibatkan kecanduan dan jika terlalu lama dan sudah ketergantungan narkoba maka lambat laun organ dalam tubuh akan rusak dan jika sudah melebihi takaran maka pengguna itu akan overdosis dan akhirnya dapat menyebabkan kematian. Dari hasil evaluasi menunjukan bahwa siswa siswi memiliki pemahaman yang meningkat dibandingkan sebelum diberikan penyuluhan tentang Napza dan dampak buruknya, sehingga meningkatkan kesadaran siswa akan dampak yang bisa ditimbulkan.

\section{Ucapan Terimakasih}

Tim pengabdian Masyarakat mengucapkan banyak terimakasih kepada Lembaga Penelitian dan Pengabdian Masyarakat Uhamka yang telah membiayai kegiatan ini, serta ucapan terimakasih tak lupa tim ucapkan kepada Kepala Sekolah SMA dan SMK Mutiara 17 Agustus yang telah bersedia menjadi mitra dalam kegiatan pengabdian ini.

\section{Referensi}

Anief. 2007. Ilmu Meracik Obat. Yogyakarta : Gajah Mada University Press.

Balai Pustaka. Laksana, P. (2004), Perubahan Sikap dan Perilaku Penyalahgunaan Narkoba, Semarang, Bengawan Ilmu

Lydia, HM. dan Joewana, S. (2006), Menangkal Narkoba Dan Kekerasan, Jakarta.

Lydia, H. dan Joewana, S. 2006, Peran Orang Tua Dalam Mencegah Dan Menanggulangi Penyalahgunaan Narkoba. Jakarta : Balai Pustaka

Priyanto. 2008. Farmakologi Dasar untuk Mahasiswa Farmasi dan Keperawatan. Jakarta : Leskonfi. Priyanto. 2009. Toksikologi, Mekanisme, Terapi Antidotum dan Penilaian Resiko. Jakarta : Leskonfi. 